Portland State University

PDXScholar

Anthropology Faculty Publications and

Presentations

Anthropology

Spring 2004

\title{
Money That Burns Like Oil: A Sri Lankan Cultural Logic of Morality and Agency
}

Michele Ruth Gamburd

Portland State University, b5mg@pdx.edu

Follow this and additional works at: https://pdxscholar.library.pdx.edu/anth_fac

Part of the Social and Cultural Anthropology Commons

Let us know how access to this document benefits you.

Citation Details

Gamburd, M. (2004). Money That Burns Like Oil: A Sri Lankan Cultural Logic of Morality and Agency. Ethnology, 43(2), 167-184.

This Article is brought to you for free and open access. It has been accepted for inclusion in Anthropology Faculty Publications and Presentations by an authorized administrator of PDXScholar. Please contact us if we can make this document more accessible: pdxscholar@pdx.edu. 


\title{
MONEY THAT BURNS LIKE OIL: A SRI LANKAN CULTURAL LOGIC OF MORALITY AND AGENCY ${ }^{1}$
}

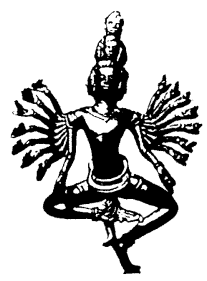

Michele Ruth Gamburd

Portland State University

\begin{abstract}
New labor opportunities have drawn Sri Lankan women to work as domestic servants in the Middle East. Many migrants complain that their remittances "burn like oil," disappearing without a trace. The gendered discourse on burning remittances both draws on and contradicts an older cultural system that fetishizes money. The emerging logic provides symbolic resources for women to spend their remittances on advancements for the nuclear family, distancing themselves from other kin. (Migration, remittances, fetishism, Sri Lanka, Middle East)
\end{abstract}

During an interview in May 2000, Nilani, who had worked for five years as a domestic servant in the Middle East, passionately remarked, "The money you earn abroad-you have to use it right away, or it will just disappear. That money burns like oil!" She explained that because employers begrudged paying their servants' wages, their ill will and dislike tainted the housemaid's money. Many such Sri Lankan labor migrants felt that unless a woman and her family used the money quickly, something bad would happen to take it away from them.

Since the early 1980 s, labor migration from Sri Lanka has burgeoned, reaching nearly one million individuals in 2002 (SLBFE 2003). In 2003, the Sri Lankan Bureau of Foreign Employment (SLBFE) estimated that 680,000 women were working abroad, over 80 per cent of them as housemaids in the Middle East (SLBFE 2003). ${ }^{2}$ For the past dozen years, I have conducted ethnographic fieldwork in the village of Naeaegama, situated near the main coastal highway in southern Sri Lanka. ${ }^{3}$ Many married and some unmarried women from Naeaegama go abroad repeatedly on two-year contracts, leaving behind husbands, children, and other family members, to whom they remit money. Over the years, the Sri Lankan government has grown increasingly dependent on labor migration to relieve local unemployment and bring in much-needed foreign exchange. Consequently, individuals, communities, and political institutions develop ever-more intricate and binding ties to the global economy (Gamburd 2003).

As they pursue these labor opportunities, Naeaegama women attribute new sorts of agentive force to fate, emotions, and money. Local people approach the phenomenon of burning remittances with degrees of literalness, ranging from a metaphoric sense of alienation (as if the worker's social circumstances took away her control over her wages) to an attribution of lifelike power and agency to the money itself. Migrants and their families currently use discourses about the agency of money (both metaphoric and fetishized) to justify new financial strategies and decrease their obligations to distant kin. An older discourse about exchange correlates with a local social structure of extended family solidarity, which provides social insurance but levels out individual advancement. The emerging discourse about exchange retains 
many of the social and moral components of the older system, including an attribution of agency to money and emotions, but changes several key elements. The new discourse supports emerging financial practices oriented to the advancement of the nuclear family. This essay explores the shifts in social and moral norms embedded in emerging local views of agency.

A spirited debate in the literature focuses on how integration into the international economy influences social relations. Few disagree that gender roles and family structures change in the wake of new economic opportunities and challenges (Fernandez-Kelly 1983:177-94; Harrison 1997; Constable 1997:vii-xiv, 17-39). Some scholars suggest that boundless human inventiveness will create coherent lived realities out of the chaos of postcolonial, postmodern society (Anderson 1994; Clifford 1994; Gupta 1992). Others feel that the capitalist market will generate an inauthentic or hyperreal culture crafted for the tourist gaze, or even a homogenized world free of local color (Garnham 1993; see also Crain 1996; Volkman 1990). In this line, Nash (2000:129) concludes, "Marx's dire predictions about the alienation of producers in a fetishized world, where all social relations would be reduced to exchange relations and measured in cash terms, has within a century and a half of his death come to pass."

But has integration into the global economy necessarily plunged all workers into alienation, let alone into a uniform and commensurable alienation? In what sense have migrant women lost control over the fruits of their toil? Evidence from Naeaegama suggests that while Sri Lankan women's domestic work in West Asia does indeed place them at a distinct disadvantage in the international division of labor, their proletarian position in the global economy does not automatically lead to a simple or straightforward understanding of alienation, to social relations reduced to exchange relations alone, or to exchange relations of a predictable and culture-free kind. Although transnational capitalism does affect concepts of money and structures of kinship, it has not (or at least has not yet) erased local concepts of morality and agency.

Just as Marx's (1967 [1867]) discussion of commodity fetishism (the attribution of agency to capital and commodities in Western capitalist culture) suggests deepseated social relations, so too in Naeaegama the burning-remittances discourse (the attribution of agency to money earned in the Middle East) simultaneously maps and obscures a social reality of labor and exchange relations between people. The distinctive Naeaegama interpretation of local and international exploitation manifests most clearly in discourses surrounding money. The local cultural logic includes a moral component concerning how money is earned and exchanged. It also includes a social component concerning the relative positions in society of the actors involved in the exchange, and the emotions they feel toward one another. How people earn money affects how they think to spend it. Migrants use the emerging discourse on agency to legitimize their choice to spend wages earned abroad for the nuclear family rather than distributing money to a wider group of relatives, a financial strategy that many villagers would not have tolerated in the past. International labor migration has 
shaped village views of money, morality, and kinship, modifying older concepts of money in new and sometimes contradictory ways. These nascent discourses surrounding money in turn transform local conceptions of people's financial responsibilities and obligations to the extended family. But contrary to Nash's (2000) assertion, local social relations have not been reduced to mere exchange relations measured in cash terms.

\section{MONEY AND AGENCY}

Simmel (1978 [1900]) suggests that money symbolizes exchange and serves to integrate society in a much more complex system than mere barter could support. The form money takes correlates with the form of society. Hart (1986:638-39) notes that in market economies, "money is at the same time an aspect of relations between persons and a thing detached from persons," evoking money's simultaneous connection to social processes and its transactional anonymity. Money is an impersonal medium of exchange, a store of wealth, a standard of value, a unit of account, and a means of deferred payments (Melitz 1970:1020; Struthers and Speight 1986:3-6). The system of money arises through collective imagination and relies on mutual trust. It reflects in microcosm the larger social world (Poggi 1993:149).

Economists rely on the presumption that "money presents a frictionless surface to history," and no one knows or cares who has owned it or how it has changed hands (Graeber 1996:6). Yet the Euro-American folk concepts of "dirty money" and "filthy lucre" suggest that moral contexts affect how people think about money. Economists often consider general-purpose money as morally neutral and usable to exchange for anything else (Codere 1968:557). But in any culture there are certain objects and services that should not be exchanged for money (Parry 1989:88); e.g., in the West, sexual favors and political influence. While economists strictly separate these cultural elements from their discussions, anthropologists have long noted the value of a holistic approach to the study of exchange (Malinowski 1984 [1922]; Mauss 1990 [1925]; Parry and Bloch 1989). The symbolic and structural properties of money reveal complex cultural logics. Many cultures share concepts surrounding ill-gotten gains (Shipton 1997), but the actions that violate norms, and the consequences that follow, vary from place to place. For example, when Euro-Americans think that money has been earned in illegal and unjust ways, they do not consider the money itself (in cash or in bank accounts) to be altered by the events. Nor, unlike some Sri Lankans, do they discuss the money owner's future in terms of possible self-initiated actions that his or her money might take.

Fetishism is the attribution of magical or lifelike power to an object. Holding a rabbit's foot to bring good luck or avoiding a tabooed food to avert disaster suggests that these items possesses power and agency. Such beliefs often index wider cultural norms and values. In his analysis of fetishism, Marx (1967 [1867]:50) focuses on the attribution of agency to capital and commodities. He suggests that in capitalist societies, labor is artificially separated from life and given a value, and that value is 
alienated from the proletarian producer and transformed into a misleading belief in the power and worth of the object (commodity) created. Attributing a value to the commodity fetishizes it; the value obscures, through "magic and necromancy" (Marx 1967 [1867]:59), the labor relations and exchange relations between people. Taussig (1980) takes this approach a step further in discussing baptized money and devil contracts, examining how postcolonial structures of power and inequality on Columbian plantations and in Bolivian mines reverberate in local categories surrounding production and exchange. Cultural concepts of value relate closely to those of personhood, agency, social relations, and morality (Breton 2000; Graeber 1996; Masquelier 1999; Osella and Osella 2000).

Notions about the nature of money that govern proper and improper modes of exchange shape actors' sense of themselves and the world around them. People always act within restrictive structures that limit the range of the choices they perceive as possible (Ortner 1989). The burning-money syndrome suggests that many Naeaegama people exchange money within a particular moral universe that reflects a local sense of justice and responsibility. They conceptualize the violation of norms and duties in terms of economic consequences exchanged as part of (or parceled with) the money itself. In the moral universe of burning money, agency does not reside solely in human beings; money and the power that adheres to it behave according to moral rules. Furthermore, people identify agentive powers in emotional energies, planetary influences, and karmic effects of past actions, all of which influence actions and outcomes.

These extended concepts of agency and causality are linked to a porous sense of personhood. People in Naeaegama see themselves and others as permeable to outside forces. In this sense, people are "fluid signs" open to and participating in their wider social environment (Daniel 1984). Similarly, the burning-money syndrome shows the importance of interpersonal mixing and mingling to personal identity, as Trawick (1990) notes in her discussion of love in a Tamil family.

Naeaegama views of money and agency (many of which run counter to Western philosophical and economic assumptions about exchange, free will, and individuality) have begun to shift and change in the face of transnational labor migration (Gamburd 2000a, 2000b). Practice theorists suggest that while structures constrain actions, through their everyday practices actors both reproduce and transform the structures that guide behavior (Sahlins 1981). Interpreting what Naeaegama villagers say about agency, causality, and personhood requires deciphering degrees of literalness. At certain times the stories suggest beliefs in animism and fetishism; at other times they suggest metaphorical ways to describe social realities.

\section{LIFE IN NAEAEGAMA}

In 1968, my mother arrived in Naeaegama with my father and me to begin her dissertation research (Gamburd 1972). I have been working in the village since 1991, and speak fairly fluent Sinhala, the local language. My two research associates and 
I have performed a thorough census, gathered kinship data, and developed a detailed map of the village. We have interviewed people from each family and have gathered life histories. We have attended funerals, weddings, and political rallies, listened to gossip, and collected jokes and stories. These research techniques provide multiple avenues of insight into what Naeaegama residents say, do, feel, and believe.

The village covers about one square mile, and in 2004 it had a population of roughly 1,100 . Most villagers live on modest housing plots interspersed between paddy fields, coconut gardens, and cinnamon estates owned by wealthy landholders. High unemployment rates show that available jobs have not kept pace with population growth. Local jobs processing cinnamon and making rope and brooms from coconut fiber provide insufficient employment. Many men now hold jobs in the armed services. Many women work in local garment factories. But the most prominent female employment is work as domestic servants in the Middle East.

Since the 1973 oil embargo, much wealth has flowed into the Middle East, which produces a quarter of the world's oil (Energy Information Administration 1997, 1999). Gulf countries hire a large number of foreign guest workers, who in recent years have come increasingly from Asia. Sri Lankan women make up about 30 per cent of the housemaids working in the Gulf. Women from Indonesia and the Philippines make up the remainder (Gamburd 2000a:34). Nine per cent of Sri Lanka's working-age women are currently employed in the Middle East (Gamburd 2000a:39). Since the early 1980s, increasing numbers of Naeaegama women have sought jobs as housemaids in West Asia. They go abroad on two-year contracts, and often return repeatedly. Over 40 per cent of Naeaegama households have or have had at least one family member working abroad. In the early 1990s, most of the migrants were married, but now a growing number are unmarried. In many cases, they pay job agents and moneylenders between US\$300-600 to procure their employment. While abroad, they earn about US $\$ 100$ a month, a wage that has held steady for the past twenty years. They send their remittances to their families, who often use the money for daily consumption. Most families hope to save enough money to buy land and build a house (Gamburd 2003). Workers' remittances around the world are "second only to oil as the single producer of the movement of funds affecting the world balance of payments" (Myron Weiner, quoted in Lelyveld 1992). Saudi Arabia alone pays a quarter of these remittances (Migration News 2001).

The livelihood of women, their families, and their communities depends on labor migration and remittances. Such a large migration stream, operating both in international and local contexts, also inevitably affects concepts of money, work, and family structure.

\section{A CULTURAL LOGIC OF LABOR AND MONEY}

The cultural logic of labor and money expressed in the phrase, "That money burns like oil," integrates several interlocking concepts. One piece of the logic considers how people make money-by hard work or through exploitative or 
fortuitous schemes-and how these methods affect the future. A second piece treats the exchange of money, including standards of fairness and reasonableness for how money changes hands. In this context, assessing fairness requires noting the social positions of the actors. A third piece rests on emotions (such as guilt, anger, greed, and jealousy), which can harm or otherwise influence people and their money. Many Naeaegama residents believe that the evil eye and a malicious tongue can lead to illness, suffering, and even death. Karmic forces (fate) and planetary influences revealed in people's horoscopes also affect economic prosperity.

\section{Money That Thrives, Money That Burns}

Money earned by "sweat and tiredness" (daadiyayi mahaansii) is good. Wages and money earned from small entrepreneurial enterprises fall into this category. Money earned through hard work will bring luck and prosperity (yaa denawaa). Such money makes a person or family thrive and flourish. Money earned through hard work will not burn. A fraction of it may go to waste, but the rest will prove fruitful and useful for the family. The opposite of money that thrives is money that burns or disappears without a trace. Money earned through exploitation or acquired by sheer chance will often burn. Many Naeaegama people feel it necessary to spend "burning money" quickly, before it figures out how to get away. They think of thriving or burning as an effect of how the money was obtained. For example, household goods purchased with burning money often prove unreliable. The money will not burn if transferred to an innocent third party; the effect usually lingers with the miscreant, but can sometimes pass to his or her family members, particularly children. Informants sometimes described burning as an active property of the money itself (fetishism); in other cases, exchanges generated bad effects that lingered with the agent but not with the transferred cash; and in still other cases, burning provided a metaphoric critique of larger social circumstances, a model for how a just world would look.

\section{Bribes}

Many activities that generate money are not associated with hard or moral work, including taking bribes, lending money, gambling, selling illicit liquor, and stealing. A complex logic governs whether money earned in exploitative ways will thrive or burn. With bribery, Naeaegama residents find one type of bribe-like gift conscionable. For example, people see no harm in a satisfied client giving a thank-you present to a helpful individual at a government agency, or school children giving cookies to their teachers. These gifts are given gladly, with pleasure, love, and respect. The money or objects received will thrive for the recipient. Villagers view as less benign the sort of bribe associated with illegal payments demanded by a person in a position of power, perhaps someone who already receives a salary to do the job in question. Naeaegama residents differ in their opinions about whether this bribe money will 
thrive for the recipient. Many say that it will not. For example, Irangani, an older woman, remarked, "If the person being bribed scares you, or demands the bribe, that isn't good. The money is given with a burning heart. It will not thrive for the person." Other villagers suggested that people pay bribes "while sighing (huul lanavaa)." The emotions behind "burning hearts" and "sighing" adversely affect the recipient of the money.

Repeatedly earning money in less than moral ways or coming into a one-time illgotten fortune, villagers say, creates a long-term effect. Some people feel that the money might help the recipient prosper for the moment, but he or she will go broke in the future. No particular bank account or purchased object carries this onus; the bad luck adheres instead to the individual or family. In contrast, some people think future prosperity will depend entirely on how the person who receives the bribe decides to use the money. These people argue that correct usage will yield a profit, and disregard what others see as the money's inherent tendency to burn. Richer villagers, particularly merchants and moneylenders, often express this sentiment. This diversity of cultural views reflects hierarchies of wealth and power within the local community.

Part of the cultural logic of money depends on the relative position of various actors within the social structure. A local astrologer suggested that whether bribe money would thrive or not depended on the relative wealth of the people giving and demanding it, and the size of the bribe. A large bribe demanded from a poor person by a relatively wealthy civil servant would not thrive for the civil servant, while a small present received by a poor bureaucrat from a wealthy person would thrive for that bureaucrat. In this way, the discourse of burning money provides a defense for the poor and powerless against the rich and influential in an economic system rife with exploitation and inequalities.

One woman, Rani, added an element of character analysis and habitual behavior. She said, “Bribes probably do thrive for their recipients, or people wouldn't ask for them! But then the recipient will go and get drunk on that money, so it won't bring him prosperity after all." A retired policeman confirmed this. He asserted that although he never asked for bribes, he and his colleagues received them anyway. They never brought goods or money from corrupt activities home because, "With that sort of money you're happy for the day, but it's bad for tomorrow." Similarly, a hospital worker who received extra money for helping with autopsies said that he never brought that money home. How they earn money influences how and when they decide to spend it. People use up burning money right away, lest it disappear and harm the domestic sphere in the process.

\section{Moneylending, Gambling, Stealing, and Selling Illicit Liquor}

Similarities and additional points arise from an analysis of moneylending, gambling, stealing, and selling illicit liquor. When asked whether money gained through these activities would thrive for the actor, informants consistently referred 
to the agentive effects of fear, anger, and greed. For example, men in the village gamble heavily during the New Year season, and sums of money equaling a month's wages change hands swiftly. An older man said, "The loser is crying and the winner is laughing. That money won't thrive for the winner." Speaking of people repaying a moneylender, a retired school principal said, "The person returns the money and the interest saying, ' $a$ poo' (my goodness! Wow! Good grief!). So that money will burn." Another person said, "People give it back it while sighing. The moneylender is eating that person's fire." This view of identity emphasizes the permeability of people to the anger, jealousy, and dislike of others with whom they transact.

I asked the astrologer about protection from cursing. He answered, "The only way is to be a reasonable person. You only really feel the effect of the curse through your own guilty heart. This is a matter of conscience, and you can't cure that except by leading a good life. If a rich person lives reasonably, then he or she doesn't need to do any rituals for protection." His comments about a bad conscience suggest that both partners in an exchange understand its moral implications; one feels righteous anger, the other guilt. The concepts of burning and thriving thus index a shared moral universe. ${ }^{4}$ Regardless of how literally people take these beliefs, the ideas shape their behavior and judgments about its merit.

Discussions of burning and thriving often contrast current wealth with destitution in the future. For example, speaking of an illicit liquor producer, the retired policeman said, "Such a person might live well for the moment, but he will die like a dog, stabbed or shot." The officer talked about this as a pragmatic matter of keeping bad company and losing the respect of the community. Others talked about it as karmic just desserts, inevitable on a moral level due to the effect of earning money in a bad way. Similar consideration of future destitution surfaced in a discussion of theft. One young man said, "If you steal or cheat, then even if you are doing it to bring food for your hungry children, it won't be good. For example, if you steal a hundred rupees and bring food, your kids will eat it and get sick, and you will have to pay three hundred rupees for medicine. This is because the person who lost the money or the item is cursing the robber." In this case the effect of a bad deed takes an immediate toll. It is transferred from the stolen currency to the purchased object (food) and passed from the sinful parent to the innocent children.

Fates worse than destitution await those who run afoul of the morality of economic exchanges. For example, the shameful activity of moneylending presents dangers to moneylenders and their families. Most moneylenders are women, and most try to maintain a low profile to minimize possible disadvantages for their families. For example, one lender kept her activities quiet to avert the bad effects for her daughters, since local people find it objectionable to use moneylending money (burning money) for a dowry. ${ }^{5}$ When another moneylender's young son inhaled a small pen piece he had been using as a whistle, the metal remained undiscovered for over a year, causing repeated bouts of bad bronchitis. The villagers blamed this bad luck in part on the mother's moneylending. A third moneylender's son died in his early twenties of cancer. In addition to discussing the cancer within the medical 
model, people said the boy got the disease from "eating" bad money. These cases reveal cultural beliefs about moneylending, gendered constraints on women's economic activities, and local assumptions about the contagious effects of ill will from mothers to children.

Thriving and burning properties of income from moneylending and gambling reveal the importance of the relative position of actors within the social structure. If a lender charges high interest from a poor person, she should feel guilty. If she charges a reasonable rate of interest from a businessman who can repay the loan easily, that money will thrive for her. The moneylender's future prosperity depends on the financial situation of the person taking and repaying the loan. Regarding gambling, the retired policeman said,

How gambling will affect the winner depends on how much harm has been done to the loser and, especially, the loser's family. The winnings might come from a house with hungry kids. If the guy wants to play just to play, that's okay, but if he takes the money for the kids' milk and his wife's dresses, that's bad. If he loses, his household falls into trouble. That curse will come to the winner. That money will burn.

The winner's future depends on the well-being of the gambler who lost. Methods of self-protection reflect the same logic of social position. The retired school principal said that a rich person could in part escape troubles by supporting an orphanage, helping a sick person, or giving money to a social service. Monetary exchanges thus express a local awareness of inequality and a sense of social justice.

The relational properties of money manifest a Robin Hood principle of theft. One informant asserted, "It's okay to steal from rich people. It's just like taking a cup of water out of the sea; they don't notice the loss." Similarly, the astrologer suggested that it was not wrong to embezzle money from government projects and nongovernmental organizations that get funding from abroad. His father-in-law disagreed, saying that to cheat or steal was wrong under any circumstances. The astrologer felt no one would notice the thefts or curse the robber; he considered the situation as a means of redistributing wealth from the complacent rich to the deserving needy. His father-in-law considered embezzlement, like theft, independent of social position or need. In this vein, some people view individuals and institutions differently. Banks charge a reasonable interest rate, but require collateral for a loan. Many Naeaegama residents have no collateral, and so borrow from moneylenders, who charge interest rates ranging from 10 to 20 per cent per month. Most women who borrow money to pay agents for jobs in the Middle East pay back twice what they borrow. Local people see interest charged by banks as reasonable; that charged by moneylenders is not. While this reflects the actual interest rates, it also reflects issues of agency. Large institutions like banks are relatively faceless, with no specific agent responsible for charging the interest. Bank employees merely do a salaried job; they do not intentionally enter into the moral universe of money exchange, and are not hurt by the borrowers' anger. In contrast, moneylenders set their own interest rates, and become vulnerable to an angry borrower's ill will. 
A similar dynamic governs the difference between local gambling and the national lottery. When lottery money is won, "it's because of merit (pin) from past lives." The retired policeman said, "No one suffers because no one lost a big amount." The reasonable stakes, the government's use of the collected funds for social services, and the lack of a village individual who profits from the gambling make the lottery morally neutral and its winnings thrive. In contrast, gambling earnings burn. Perceptions of moral responsibility shape these contrasting views.

Character assessment and notes on habitual behavior also entered into discussions of gamblers' spending habits: "They don't make houses with it; they just finish it all up right then and there." Some people feel that if gamblers buy household goods with their winnings, they can counter the money's tendency to burn. Others (the majority) feel that the loser's anger will intensify in the face of obvious and visible reminders of his loss and another's gain. By spending or losing such winnings quickly, without visible improvement, the winner defends himself by dispersing possible envy and jealousy. Thus people's expectation that the money will burn influences how they spend it. Profligate spending, then, reinforces the association between method of gain and style of spending.

\section{EMERGENT CHANGES}

The aspects of cultural logic set forth above form the context in which to interpret the phrase, "That money burns like oil!" Many migrants and their families make remarks to this effect, and, more importantly, act according to the common sense encoded therein (Gramsci 1988). The notion of burning remittances both reproduces and transforms the general patterns discussed earlier. Although cultural norms predispose actors to think and act in certain ways, the accumulation of irregular or deviant actions can stretch and change the cultural categories that designate the norm. In Naeaegama, alterations in the cultural logic of money manifest themselves in linguistic patterns, financial decisions, and changing obligations to extended kin.

\section{Contradictions}

The idea that remittances burn contradicts older views of money in a number of ways. First, most migrants agree that they work hard abroad. Domestic servants toil long hours with few or no days off. According to the moral logic revealed in the cases discussed earlier, hard, honest work guarantees that wages will thrive for the worker. In this case, however, another factor intervenes. Housemaids argue that their employers dislike them. Nilani said, "The people in Kuwait don't have kind hearts," and offered the following story:

There was a Sri Lankan New Year holiday festival in Kuwait, and one housemaid was chosen Avuruddhu Kumari (New Year Princess). The judge asked her how she liked the place where she worked. She said that it was a very good place, and that the Madam was better even than her own 
mother. All the housemaids laughed and hooted because they didn't believe her. No matter how hard you work, those people don't think you've done enough. The Arabs resent paying your wages, so you have to use that money fast because it won't keep. That money burns like oil!

Repeating stories of this nature reinforces a common Sri Lankan stereotype of Arab employers as angry, grouchy, and mean. Stories and stereotypes "can be read as archives on the human condition that give figurative expression to unresolved antagonisms" (Gregory 1996:197).

In the burning-remittances syndrome, emotions create an after-effect, giving agentive powers to the money, which strives to disappear without thriving. But the idea that a grouchy employer can make a hardworking housemaid's money burn provides a second contradiction. Relational dynamics addressed earlier suggest that in a moral conflict between richer and poorer people, a moral universe will conspire to favor the poor. This suggests that the moral workings of money exchange should protect a poor, hard-working woman from her employer's unreasonable grudge, much like the Robin Hood principle in part protects a poor person who steals from a rich one. A person who lives reasonably with a clear conscience should find that money thrives for her. But despite this, women say that their wages burn. These contradictions suggest that remittances from the Middle East burn in a different moral context from other money. The changes reflect recent trends in female labor migration, and prefigure new family financial strategies.

\section{Different Views on Burning Remittances}

Naeaegama villagers voiced different points of view on remittances. Nonmigrants see burning as an excuse for migrant families' bad planning. Numerous informants argued that some migrants did very well with foreign money; they built houses, bought cinnamon gardens, and set up stores. These informants suggested that if some people can do well with Middle Eastern money, then the money in general is not harmful and the fault lies with the Sri Lankan spenders, not their Arab sponsors. "Some people use the money well, some waste it." The retired policeman said, "You need to be able to manage your money. You need to know how to spend it." Like richer villagers who denied the bad effects of immoral money transfers in the older cultural logic, these individuals see the lack of prosperity as an outcome of unsound financial decisions, not Arab hostility.

The retired policeman and his wife (neither of whom has been to the Middle East) suggested three reasons that remittances did not really burn (due to money's agentive activities), but only seemed to burn (due to migrants' poor financial planning). Their list reflects local realities and widely prevalent caricatures and stereotypes of migrants held by nonmigrants. First, the policeman's wife suggested that some housemaids borrow money at 20 per cent interest from the moneylender and that it takes them eight months to a year just to pay back their loan. "No wonder their wages disappear!” This assessment of migrants' financial situations closely 
mirrors the actual situation, but the migrants themselves do not discuss burning in terms of repaying debts.

Second, the couple suggested that some migrants and their families want to have "a TV and lots of parties" when the woman returns to Sri Lanka. When the family had spent all their money, the woman would go back to the Middle East to earn more. This critique typifies the assumptions of a hedonistic wastefulness that many nonmigrants hold of migrants and their families. Migrants themselves talk about more pressing and immediate needs than for television sets and parties, but do acknowledge that their money does get spent quickly without much of lasting material worth to show for it. For example, a mother of ten said that the money her daughter sent home vanished because she had so many people to feed, and relatives would ask to borrow cash. If someone in her extended family lacked food or medicine, then she provided it out of her daughter's money. This money burned even though her daughter had a good employer. Similarly, a recently returned migrant who had worked six years for a good house said, "My money burns in five minutes! Smart people can use this money, but I just give it away and finish it off. My son says I have no brain, and he criticizes me for giving presents to everyone. He doesn't spend money foolishly. He still has the 200 rupees I gave him when I came home." When these women say that their remittances burn, they mean that it disappears without much trace among needy friends and relatives.

A third reason why money seems to burn, the retired policeman and his wife suggested, is that women often send money to husbands who eat, drink, and sit around idly. This popular stereotype has developed a degree of agency, and migrants' husbands often feel the need to counter what they assume others will have assumed about them, even while accepting the stereotype as true for other husbands. One man noted, "Some people get money from their wives and then drink, gamble, and party until it's gone. But I didn't waste even five cents' worth of my wife's money." Some men do indeed waste money, but nowhere near as many or as much as the caricature suggests (Gamburd 2002). Through economic choices, women and their families work against the images of the wasteful husband and the pleasure-seeking family.

\section{Countering Burning}

Over the past two decades, Naeaegama migrants have developed financial strategies to limit the burning of their remittances, which they identify as distribution of money through many small gifts to friends and extended family. The notion of burning remittances represents a reconfiguration of older ideas. As the concepts stretch to accommodate emerging realities, contradictions arise. When women leave Naeaegama to work abroad, they violate older gendered ideals by depriving their families of their domestic labor. Migrants almost always cite as their incentive the financial necessity of supporting their families' daily consumption, with the added hope of saving money to buy land and build a house. Remittance checks, new shoes, fancy pencil cases, cassette players, refrigerators, and above all the foundations for 
a large cement house stand in for the absent wife and mother. The grand-scale consumption of buying or building a house permanently communicates an absent woman's devotion to her nuclear family.

The new discourse on burning remittances allows new spending habits; in particular, a woman spends money all at once on a big purchase for her nuclear family, instead of spending it in dribs and drabs for the rest of the extended family as older social norms require (Gamburd 1998). The retired school principal (whose three daughters had worked abroad) insisted on the fairness of such spending, saying, "Economic savings isn't stinginess or greed. You must save. You must have control." By shifting agency from individual people to the money itself, the discourse helps justify this new pattern. In this view, by buying land and building a house, women and their immediate families have acted to counter their money's tendency to burn, and they have not slighted their relatives or ignored their family obligations. Racist stereotypes of angry Arab employers provide the discursive resource to legitimize new forms of consumption and new kinship dynamics.

Rani summarized the new discourse's dictates on when to spend, stating, "You have to use that money straight away. If you don't use it fast, it will burn." Migrant women often save their money in foreign currencies, either in Sri Lanka or abroad, bringing it home in one lump sum and spending it soon after their arrival. Given inflation and devaluation of the Sri Lankan rupee, money saved in cash or in a bank may lose real value though remaining equal or growing slightly in nominal value. Given the many pressing needs for money in the local economy, money remitted to relatives is often spent before the woman's return. Thus the new ideas about remittances dictate economically sound financial decisions.

The new discourse, Rani noted, also suggests how to spend money. "Money in the bank will vanish; if you start a business, it will go bankrupt. Invest in land and a house." Phenomena discussed within the discourse as propensities of the money reflect the reality that many small businesses do go under, especially when run in difficult economic circumstances by inexperienced and untrained people. Most villagers choose to invest in land, a house, and providing dowries for their daughters, turning to business ventures only when they have achieved a certain level of domestic stability (Gamburd 2003). Although the idea of using money as capital to earn more money makes sense in abstract economic terms, a decade of government-initiated self-employment schemes has left Naeaegama villagers wary of the risks of entrepreneurial activities. Folk theories of money present the distilled essence of local encounters with the national and international capitalist economy.

Gender ideologies constrain spending habits. In many areas of Sri Lanka, women bear the responsibility for managing the household finances; people assume that men will fritter away any resources their wives fail to commandeer (Stirrat 1989:99). These stereotypes shape behaviors. Many men do in fact quickly spend money from bribes, autopsies, and gambling on frivolous and pleasurable expenditures. Although female migration presents a radically new labor situation, their wages' alleged agency and will to disappear, coupled with older norms of female financial responsibility, 
constrain what women desire and how they spend their earnings. The new discourse empowers women to spend burning remittances in a useful manner, one that runs counter both to pursuit of individual gratification and to older obligations for sharing with and helping distant relatives. In the past, generalized reciprocity along kin networks provided very poor people with an insurance system in the domestic economy but inhibited the accumulation of wealth by individuals or nuclear families (Weismantel 1995). Naeaegama women's emerging spending habits reflect a change in class position, with nuclear families transforming their obligations to kin as they move up in the social structure (Gamburd 1999; Stack 1970). A newly prioritized object of desire (a plot of land and a house) supersedes both the Western ideal of luxury consumption and the older ideal of a strong family support network.

\section{CONCLUSIONS}

The discourse on burning remittances raises two issues for the study of agency: first, the question of how new economic opportunities affect norms surrounding gender roles, kinship duties, and moral responsibilities; and second, the question of how the purported agency of things supposedly lacking volition (such as money and emotions) limits or enables individual actors. Increasing integration into the international labor market is transforming the material and social contexts in which migrant women and their families act, choose, and live.

Two different but linked cultural logics of value and morality currently coexist in Naeaegama. Money from bribes, gambling, moneylending, stealing, and selling illicit liquor burns in a moral universe that governs face-to-face exchanges in a local network. This morality assigns a disciplinary agency to transfers of money that directs the "haves" to share with the "have-nots" (or at least to treat them fairly). Certain institutions, such as banks and lotteries, escape this moral discipline because the people involved do not act in agentive or intentioned ways. Of course, not everyone shares these views or takes these ideas literally. Some people, especially the rich, deny the agentive character of monetary exchanges. They view money in a more Western way, thinking that it should be profitable if spent and invested wisely.

Money earned in the Middle East burns in a different moral universe. One might assume that money earned abroad, like that saved, borrowed, stolen, or won from faceless institutions like banks, government projects, NGOs, and lotteries, would have a morally neutral or "frictionless" quality in transaction. But the emerging discourse on remittances provides financial transactions of transnational migration with a face: the stereotype of the bad-hearted employer.

The contradictions inherent in the emerging discourse on burning remittances index growing tensions between nuclear and extended families. The newer cultural logic pushes women to spend their wages in a fashion that most favors their immediate kin. Marx and Simmel both suggest that the capitalist economy enhances indifferent, depersonalized relationships and promotes "the growth of individualism and the destruction of solidary communities" (Parry and Bloch 1989:4). In the 
Naeaegama case, citing the dangerous agency that their employers' anger imparts to their money, women make decisions that cut off more distant relatives from the fruits of their labor. Although these actions do undermine the older, kin-based insurance networks, they are less a destruction of community than efforts to qualitatively transform a nuclear family's class status. Through the grand-scale consumption of buying land and building a house, migrants and their families also offset the negative stereotypes of wasteful husbands, negligent wives, and hedonistic families. Naeaegama villagers resourcefully use the negative caricatures that pervade the discourse to justify their financial decisions.

A poststructuralist analysis raises the question of who produces, distributes, and consumes this discourse, for what reasons, and with what effect (Williams 1977). Naeaegama villagers move easily between an animist fetishism (feared but not fully believed) and a metaphoric expression of widely accepted moral criticism (less frightening but harder to dismiss). At times these issues simmer below the level of critical thought; at other times they boil over into open contention in the village. Structured discourses about money both constrain and enable individual agency. The older discourse assigns a disciplinary agency to money that operates to humble the powerful and protect the poor. On one hand, by giving anger agentive force, the discourse acknowledges exploitation and deplores unequal social status, functioning as a statement of power by the disempowered. On the other hand, this set of ideas deflects concrete and material actions of the poor for their own advancement by focusing attention on the indirect efficacy of emotional energies instead. The burningmoney discourse works through both consent and coercion, making it difficult to distinguish resistance from acquiescence in any simple or unambiguous way (Ahearn 2001). Here is a dual power dynamic: the poor perpetuate the discourse to humble the rich, and the rich perpetuate it to defang the poor, with each side understanding at least a little of the other's motives, and with both sides believing at least a little in the other's explanatory logic.

In sum, the emerging discourse on burning remittances presents a polyvalent text on power and inequality. It acknowledges in symbolic form the practical exigencies of exploitation and disempowerment inherent in the international division of labor and the local economy. It can also be read as justification for recent changes in gendered obligations to extended families. The hard-hearted employers in the Middle East take the blame for infusing money with a character or agency that requires a woman to spend her wages in a lump sum on her nuclear family rather than redistributing it to the needy in her wider family sphere. In this cultural logic, an agent's position in the social structure still matters, but it no longer protects the hard-working laborer from the unjust burning of her money. Although in the older discourse the emotions of the underdog could harm a wealthy moneylender, the new system does not punish the haughty rich: a housemaid's anger does not affect her Arab employers, ${ }^{6}$ and poor relatives' wishes do not outweigh the needs of the nuclear family. Nonetheless, integration into the global capitalist system has not (yet) reduced social relations to mere exchange relations measured in cash terms (Nash 2000:129). Migrant women 
and their families struggle to reassess morality and agency in a globalizing economic world.

\section{NOTES}

1. This research was supported in part by National Science Foundation grant number SBR-9903314. My thanks go to Laura Ahearn, Denise Hare, Webb Keane, Charlene Makley, and Anupama Rao for their insights and suggestions.

2. Throughout this essay the terms "Middle East," "West Asia," and "the Persian Gulf" interchangeably designate the oil-producing nations of Bahrain, Kuwait, Qatar, Saudi Arabia, and the United Arab Emirates.

3. The names of places and people have been changed to protect the informants' privacy.

4. Compare Taussig (1980:110) on Columbian plantation owners who fear the sorcery of their workers: "The people who believe in sorcery recognize that the sorcerer's power depends upon the existence of a shared culture, through which medium sorcery achieves its end."

5. Compare Shipton (1997:173) on Luo beliefs that if people use "bitter money" for bridewealth payments, the bride will sicken and die.

6. Although housemaids do not sense their own power in this regard, employers fear the ill will of their domestic servants, particularly their abilities to spread malicious gossip, mistreat children, and adulterate food.

\section{BIBLIOGRAPHY}

Ahearn, L. 2001. Language and Agency. Annual Review of Anthropology 30:109-37.

Anderson, B. 1994. Exodus. Critical Inquiry 20(2):314-27.

Breton, S. 2000. Social Body and Icon of the Person: A Symbolic Analysis of Shell Money among the Wodani, Western Highlands of Irian Jaya. American Ethnologist 26(3):558-82.

Clifford, J. 1994. Diasporas. Cultural Anthropology 9(3):302-38.

$\rightarrow$ Codere, H. 1968. Money-Exchange Systems and a Theory of Money. Man n.s. 3(4):557-77.

Constable, N. 1997. Maid to Order in Hong Kong: Stories of Filipina Workers. Ithaca.

Crain, M. M. 1996. Negotiating Identities in Quinto's Cultural Borderlands: Native Women's Performances for the Ecuadorean Tourist Market. Cross-Cultural Consumption, ed. D. Howes, pp. 125-37. New York.

Daniel, E. V. 1984. Fluid Signs. Berkeley.

Energy Information Administration. 1997. The World Oil Market. http://www.eia.doe.gov/oiaf/ieo97/ oil.html.

1999. Persian Gulf Oil Export Fact Sheet. http://www.eia.doe.gov/emeu/cabs/pgulf.html.

Fernandez-Kelly, M. P. 1983. For We Are Sold, I and My People: Women and Industry in Mexico's Frontier. Albany.

Gamburd, G. 1972. The Seven Grandparents: Locality and Lineality in Sinhalese Kinship and Caste. Ph.D. dissertation, Columbia University. New York.

Gamburd, M. 1998. Absent Women and Their Extended Families: Sri Lanka's Migrant Housemaids. Negotiation and Social Space: A Gendered Analysis of Changing Kin and Security Networks in South Asia and Sub-Saharan Africa, eds. C. Risseeuw and K. Ganesh, pp. 276-91. New Delhi.

1999. Class Identity and the International Division of Labor: Sri Lanka's Migrant Housemaids. Anthropology of Work Review (19)3:4-8.

2000a. The Kitchen Spoon's Handle: Transnationalism and Sri Lanka's Migrant Housemaids. Ithaca.

2000b. Nurture for Sale: Sri Lankan Housemaids and the Work of Mothering. Home and Hegemony, eds. S. Dickey and K. Adams. Ann Arbor. 
2002. Breadwinners No More: Identities in Flux. Global Women: Nannies, Maids, and Sex Workers in the New Economy, eds. A. Hochschild and B. Ehrenreich, pp. 190-206. New York.

2003. In the Wake of the Gulf War: Assessing Family Spending of Compensation Money in Sri Lanka. International Journal of Population Geography 9(6):503-15.

Garnham, N. 1993. The Mass Media, Cultural Identity, and the Public Sphere in the Modern World. Public Culture 5(2):251-65.

Graeber, D. 1996. Beads and Money: Notes towards a Theory of Wealth and Power. American Ethnologist 23(1):4-24.

Gramsci, A. 1988. An Antonio Gramsci Reader: Selected Writings, 1916-1935, ed. D. Forgacs. New York.

$\rightarrow$ Gregory, C. A. 1996. Cowries and Conquest: Towards a Subalternate Quality Theory of Money. Society for Comparative Study of Society and History 38(2):195-217.

Gupta, A. 1992. The Song of the Nonaligned World: Transnational Identities and the Reinscription of Space in Late Capitalism. Cultural Anthropology 7(1):63-79.

Harrison, F. V. 1997. The Gendered Politics and Violence of Structural Adjustment. Situated Lives: Gender and Culture in Everyday Life, eds. L. Lamphere, H. Ragone, and P. Zavella, pp. 451-68. New York.

Hart, K. 1986. Heads or Tails? Two Sides of the Coin. Man (n.s.) 21(4):637-56.

Lelyveld, M. S. 1992. Middle East Experts Weigh Effect of Labor Mobility on Economies. Journal of Commerce, 18 February.

Malinowski, B. 1984 (1922). Argonauts of the Western Pacific: An Account of Native Enterprise and Adventure in the Archipelagoes of Melanesian New Guinea. Prospect Heights.

Marx, K. 1967 (1867). Das Kapital: A Critique of Political Economy. Chicago.

Masquelier, A. 1999. "Money and Serpents, Their Remedy is Killing": The Pathology of Consumption in Southern Niger. Research in Economic Anthropology 20:97-115.

Mauss, M. 1990 (1925). The Gift: The Form and Reason for Exchange in Archaic Societies, transl. W. D. Halls. New York.

Melitz, J. 1970. The Polanyi School of Anthropology on Money: An Economist's View. American Anthropologist 72(5):1020-40.

Migration News. 2001. Remittances. http://migration.ucdavis.edu:80/Data/remit.on.www/ AboutRemit.html.

Nash, J. 2000. Global Integration and the Commodification of Culture. Ethnology 39(2):129-31.

Ortner, S. 1989. High Religion: A Cultural and Political History of Sherpa Buddhism. Princeton.

Osella, F., and C. Osella. 2000. Migration, Money and Masculinity in Kerala. Journal of the Royal Anthropological Institute 6(1):117-33.

Parry, J. 1989. On the Moral Perils of Exchange. Money and the Morality of Exchange, eds. J. Parry and M. Bloch, pp. 64-93. Cambridge.

Parry, J., and M. Bloch (eds.). 1989. Money and the Morality of Exchange. Cambridge.

Poggi, G. 1993. Money and the Modern Mind: Georg Simmel's Philosophy of Money. Berkeley.

Sahlins, M. 1981. Historical Metaphors and Mythical Realities. Ann Arbor.

Shipton, P. 1997. Bitter Money: Forbidden Exchange in East Africa. Perspectives on Africa: A Reader in Culture, History and Representation, eds. R. R. Grinker and C. B. Steiner, pp. 163-89. Oxford.

Simmel, G. 1978 (1900). The Philosophy of Money. New York.

SLBFE (Sri Lanka Bureau of Foreign Employment). 2003. Statistical Handbook on Migration, 2002. Colombo.

Stack, C. B. 1970. All Our Kin: Strategies for Survival in a Black Community. New York.

Stirrat, R. L. 1989. Money, Men and Women. Money and the Morality of Exchange, eds. J. Parry and M. Bloch, pp. 94-116. Cambridge.

Struthers, J., and H. Speight. 1986. Money: Institutions, Theory, and Policy. London. 


\section{ETHNOLOGY}

Taussig, M. 1980. The Devil and Commodity Fetishism in South America. Chapel Hill.

Trawick, M. 1990. Notes on Love in a Tamil Family. Berkeley.

Volkman, T. A. 1990. Visions and Revisions: Toraja Culture and the Tourist Gaze. American Ethnologist 17(1):91-110.

Weismantel, M. 1995. Making Kin: Kinship Theory and Zumbagua Adoptions. American Ethnologist 22(4):685-704.

Williams, R. 1977. Marxism and Literature. Oxford. 